Studies in African Linguistics

Volume 32, Number 2, 2003

\title{
TONAL ALTERNATIONS IN THE URHOBO NOUN PHRASE
}

\author{
Rose O. Aziza \\ Delta State University
}

Urhobo is an Edoid language spoken extensively in Delta State, Nigeria. This paper examines tonal alternations in the Urhobo noun phrase with a view to providing more data that can lead to a better understanding of tonal behavior in Edoid languages. The language has two basic tones, high and low, two gliding tones, high-low (falling) and low-high (rising), plus a phenomenon of downstep, both automatic and non-automatic. A number of noun phrases are examined here and, as will become obvious later, the language relies heavily on tone to express many grammatical categories. The main points of interest from this study include the preservation of $\mathrm{H}$ at the expense of $\mathrm{L}$, the fact that the loss of $\mathrm{L}$ does not result in downstep, that ' $\mathrm{H}$ plus following $\mathrm{H}$ can give $\mathrm{H}$ so the downstep can be deleted, and that there are syntactically conditioned floating $\mathrm{H}$ tones in certain constructions.

\section{Introduction}

Since Urhobo is not yet a well studied language, a brief mention of its sounds is necessary here. The sounds of Urhobo are given in Tables 1 and 2 below.

Table 1: Urhobo Consonant Sounds

\begin{tabular}{|c|c|c|c|c|c|c|c|}
\hline & Bilabial & $\begin{array}{l}\text { Labio- } \\
\text { dental }\end{array}$ & Alveolar & $\begin{array}{l}\text { Palato- } \\
\text { alveolar }\end{array}$ & Palatal & Velar & $\begin{array}{l}\text { Labial- } \\
\text { velar }\end{array}$ \\
\hline Plosive & $\mathrm{p}$ & & $\mathrm{t}$ & & $\mathrm{c}$ & $\mathrm{k} \quad \mathrm{g}$ & $\mathrm{kp} \mathrm{gb}$ \\
\hline Fricative & $\varphi$ & $\mathrm{v}$ & $\mathrm{s}$ & $\int$ & & $\mathrm{h} \quad \gamma$ & \\
\hline Nasal & $\mathrm{m}$ & & $\mathrm{n}$ & & $\mathrm{n}$ & $\mathrm{n}$ & \\
\hline Trill/tap & & & $r$ & & & & \\
\hline Flap & & & f & & & & \\
\hline Approximant & & $v$ & & & j & & $\mathrm{w}$ \\
\hline
\end{tabular}


The language also has seven phonetic vowels but nine phonological vowels. This is because the vowels /e/ and /o/ behave sometimes as low vowels and sometimes as high vowels in their vowel harmony requirements when they occur in sequences. We shall not, however, discuss that here. Only the seven phonetic vowels, which are also the orthographic vowels, will be presented. There is no contrastive vowel length, although vowels appear to have greater duration when they bear a contour tone.

\section{Table 2: Urhobo Vowel Sounds}

$\begin{array}{ll}\mathrm{i} & \mathrm{u} \\ \mathrm{e} & \mathrm{o} \\ \varepsilon & \mathrm{o}\end{array}$

a

The Urhobo tone system has been studied by Kelly (1969), Welmers (1969, 1973), Elugbe (1973, 1989) and Aziza (1997). It has a terraced level tone system with the following characteristics. Only vowels bear tones in this language. There are two basic tones, low (L) and high $(\mathrm{H})$. Consecutive tones are realized on the same pitch level. There are also two gliding tones, HL (falling) and LH (rising) which are generally derived from the basic tones in a relatively few syntactic contexts outside the noun phrase. There are no lexical contour tones. However, the digits in the numeral system display a LH contour in their citation forms, and will be discussed in the appropriate section. There is non-automatic downstep $(' \mathrm{H})$ which Welmers regards as a mid tone. His analysis is not surprising since this pitch acts phonologically "special" in ways that are somewhat suggestive of being a $\mathrm{M}$ tone. It is found only after $\mathrm{H}$, especially in the final position of some nouns and numerals. It is not traceable to a lost $L$ tone, but it has a lowering effect on the pitch of a following $\mathrm{H}$ such that after it, a following $\mathrm{H}$ is realized on the same pitch as ' $\mathrm{H}$ and no succeeding tone can rise significantly higher than its level within the same tone phrase. Downstep can be deleted from the phonetic string due to certain phonological processes, and when that happens, the lost ${ }^{\prime} \mathrm{H}$ has no lowering effect on surviving tones (see e.g. section 2.1). There is phonetic downdrift such that in a $\mathrm{H}-\mathrm{L}-\mathrm{H}$ sequence, the second $\mathrm{H}$ is realized on a pitch level lower than the initial $\mathrm{H}$, but for this to take place, the $\mathrm{L}$ tone must be phonetically 
realised. Where, due to phonological processes, it gets deleted from the phonetic string, it does not lower a $\mathrm{H}$ tone.

Most nouns in Urhobo are either disyllabic or trisyllabic and usually have the structure prefix + stem. The prefix is always a vowel while the stem always begins with a consonant. Prefix vowels of nouns and adjectives usually alternate to reflect number concord. The plural prefix appears in two phonological shapes $[\mathrm{i}-] \sim[\mathrm{e}-]$, the choice of which depends on the ATR vowel harmony requirements of the stem: [+ATR] vowels select [i-] while [-ATR] vowels select [e-]. Most Urhobo personal names are phrases or even sentences but they can be shortened, and when this is done, they may appear with or without a prefix vowel. For example, ['óỳnétégà] 'God is worthy to be worshipped' is usually realized simply as [tégà] 'worthy to be worshipped' while [ònànèfè] 'this is wealth' is usually realized as [èfè] 'wealth'. However, as we shall see later, when such forms occur in certain phrases, a low-toned [i-] prefix is always introduced irrespective of the type of vowel in the stem, an indication that the deletion of the prefix vowel may be only a surface structure phenomenon. Many nouns differ in meaning only because they differ in tone. On the basis of tone patterning, Urhobo disyllabic and trisyllabic nouns in their citation form can be classified into five and ten tone groups respectively as in (1) and (2) below. (Note: in this paper, the tones will be marked as follows: the low tone as [' ], the high tone [' ], and the non-automatic downstep as $\left[^{-}\right]$on the vowel bearing the tone).

(1) Disyllabic Nouns
a. low - low
(L-L)
'line'
b. low - high
(L-H)
ùsí
'starch'
ùkpè 'year'
c. high - high
úkó
(H-H)
d. high-low
úkpè
'cup'
(L-H)
e. high - downstep
óḡ
'bed/bedroom' tégà personal name
(H-'H)
'in-law'
jòj 'bottle'
k'́vé personal name
'i

\footnotetext{
${ }^{1}$ This personal name means 'gave me' and comes from [óyżnćk'́vé] spelt as Oghẹnẹkẹvwẹ meaning 'God gave me').
} 
(2) Trisyllabic Nouns
a. high-high-high ágádá
b. high-high-downstep órérē
c. high-high-low ónógbò
d. high-low-high ódibó
e. high-low-low égòdò
f. low-high-high
iŕnbó
g. low-high-downstep ùkútā
h. low-high-low èrákò
i. low-low-high ègbèdé
j. low-low-low òdibò

\section{(H-H-H)}
'matchet'
( $\left.\mathrm{H}-\mathrm{H}-{ }^{\prime} \mathrm{H}\right)$
'town, city' úkókō 'association, meeting'
(H-H-L)
'pussy cat' ítábà 'tobacco'
(H-L-H)
'banana'
(H-L-L)
'compound' śàrè 'man'
(L-H-H)
'pepper'
(L-H-'H)
'stone'
(L-H-L)
'dog'
(L-L-H)
'needle'
(L-L-L)
'servant, slave' òhòrè 'neck'
éhóhó 'a hidden corner'

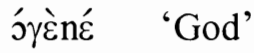
iséné 'camwood'
èwérī 'monkey'
ijérè 'road'
òkpètú 'trouble'

It should be noted, though, that the group of nouns here labeled H-L-H are actually closer in pitch to H-M-M but since the basic tones of the language are $\mathrm{H}$ and $\mathrm{L}$, we identify them as $\mathrm{H}-\mathrm{L}-\mathrm{H}$ rather than as $\mathrm{H}-{ }^{\prime} \mathrm{H}-\mathrm{H}$.

Welmers (1969: 94) states that the mid tone, which we regard as a downstep, occurs only after a $\mathrm{H}$ tone and in final position of some nouns and numerals and that it becomes low when anything at all follows it. His examples include:
a. ว́s $\bar{\varepsilon}$ 'father'
ว́š̀ wé
'your father'
b. 'i $\gamma \bar{o}$ 'money'
íyò nànà
'this money'

While our data attest to the fact that ${ }^{\prime} \mathrm{H}$ is found only after $\mathrm{H}$ and in final position, ' $\mathrm{H}$ does not actually become $\mathrm{L}$ when followed by another tone: the examples in (4) show that HL and $\mathrm{H}^{\prime} \mathrm{H}$ contrast phrase-medially such that (4a) surfaces as H-M-M and (4b) as H-L-M since there is downdrift in the language. 
(4)

a. $[---]$

[ós $\bar{\varepsilon} \mathrm{w} \varepsilon$ ]

'your father'

$\mathrm{H}^{\text {' }} \mathrm{H} \quad \mathrm{H}$

father your

[H M M]

b. $\quad[-,-]$

[ókà wé] 'your maize'

$\mathrm{H}$ L H

maize your

[H L M]

In this paper, our main focus is on the behavior of tone in the noun phrase.

\section{Tonal alternations in the noun phrase}

In general, a simple noun phrase consists of a noun and a modifier, and the modifiers are of different types. From the way the NPs pattern, it is possible to classify them into five broad groups: non-associative, associative, noun+relative, noun/ noun phrase doubling, and noun reduplication. In terms of tonal alternations, our data reveals the following generalizations:

- that there are tone changes resulting from the merging of vowels which illustrate the principle that $\mathrm{H}$ tones are preserved at the expense of L tones;

- that when a L tone between two $\mathrm{H}$ tones gets deleted, a downstep does not result, in contrast to what occurs in many languages that have downstep;

- that ${ }^{\prime} \mathrm{H}$ becomes $\mathrm{H}$ when merged with an immediately following $\mathrm{H}$ tone in certain constructions; and

- that floating $\mathrm{H}$ tones exist in this language, which provides another way of illustrating these tone principles independent of vowel deletion.

2.1 Non-associative noun phrases. The structure of the NPs in this group is an N followed by its modifier(s). The modifiers, except the class of numerals, comprise a prefix vowel (which alternates to reflect number concord) and a stem. The prefix vowels of the definite article, the demonstrative and the possessive pronouns (first and second person singular forms only) bear L tones and when they follow the noun, both the prefix vowel and its L tone are deleted; the result is that there are no tone alternations in the noun. The independent forms of the modifiers are: 
(i) Definite article: jòn 'the (sing.)/this' ènà 'the (pl.)/these' j̀jè 'that' èjè 'those'

(ii) Demonstrative: ònànà 'this one' ènànà 'these ones' jjènà 'that one' èjènà 'those ones'

(iii) Possessive Pronoun: (first and second person singular forms only) ว̀m $\varepsilon$ èmé 'my, mine' ว̀wع́ èwé 'your, yours'

These forms feature in the NPs in (5) below:
a. úkpè j̀nà
[úkpè nà]
bed the
'the bed'
b. íkó ènà
[íkó nà]
cups the
'the cups'
c. úkpè j̀nànà
[úkpè nànà]
bed this (one)
'this bed'
d. íkó ènànà
[ikó nànà]
cups these
e. úkpè ذ̀mé
'these cups'
[úkpè mé]
bed $\quad \mathrm{my} / \mathrm{mine}$
'my bed'
f. 'íkó èwé
[ikó wé]
cups your/yours
'your cups'

Welmers (1969) rightly lists jróbồ 'that one over there' as one of the demonstratives but this form actually belongs to the associative construction to be discussed in 2.2 .

The indefinite article jvò ' $a$, an, one' alternates with èvò 'some'; it also follows its noun and bears $L$ tones but unlike in the constructions above, it is the final vowel of the noun which either gets elided if it is [-high] or undergoes glide formation if it is [+high]: however, its tone remains, again demonstrating the retention of $\mathrm{H}$ tone at the expense of $\mathrm{L}$ tone. The noun's tone either merges with the tone of the prefix vowel of the modifier if it is also $\mathrm{L}$ as in $(6 \mathrm{a})$ and $(6 \mathrm{~b})$ or replaces it if it is $\mathrm{H}$ or ${ }^{\prime} \mathrm{H}$ as in $(6 \mathrm{c}, \mathrm{d})$, evidence that the $\mathrm{H}$ tone is preserved at the 
expense of the $\mathrm{L}$ tone.
a. úkpè jvò
bed a, one
$=$ [úkpòvò]
'a/ one bed'
b. àbj̀ èvò ènà = $=$ [àbèvò nà]
hands some the
c. íkó èvò = [ikévò]
cups some
d. ós $\bar{\varepsilon}$ jvò
'some cups'
father a, one
[ósว̄vò]
'a, one father'

A wh- modifier also behaves in a similar way but since these are usually questions, the L question tonal morpheme (hereafter referred to as "tomorph") attaches to the final vowel which already bears a $\mathrm{H}$ tone, and a $\mathrm{HL}$ contour is thereby created. In (7b) the tone immediately following ' $\mathrm{H}$ is $\mathrm{L}$ and so ' $\mathrm{H}$ survives while $\mathrm{L}$ is deleted. For example:
(7)
a. ìvèvì ibró
(L)
$=$ [iwèvì brô]
houses how many $\mathrm{Q}$.
b. és̄èvó
(L) $\quad=$ 'ésēvô]
fathers which
Q.
'which fathers?'

Nouns may also be followed by numeral modifiers. Welmers (1969) gives a good, broad account of the numeral system of Urhobo and, as he correctly observes, the system is basically vigesimal, i.e., based on 'twenty' with a subordinate decimal division based on 'ten'. Among the digits 'one' through 'ten', only /ovò/ 'one' begins with a $\mathrm{L}$ tone. Welmers analyzes the initial tone of the digits 'two' through 'ten' as $\mathrm{H}$ but we believe that that tone is better analyzed as a $\mathrm{LH}$ contour for two main reasons. First, in the citation form of these digits, an initial LH contour is clearly perceived. The point must however be made that the tone contour is quick such that it can easily be simplified to $\mathrm{H}$. Moreover, the $\mathrm{LH}$ contour appears to be a property only of the digits other than 'one', as these constitute the only group of words found with a contour tone in the citation form in this data. Other cases of tone contours are derived from the juxtaposition of the two basic tones on one vowel in certain grammatical constructions.

Second, following Welmers' analysis where the numerals have initial $\mathrm{H}$ tone, the forms in (8) and (9) below should have similar outputs in the surface but they do not. Whereas in (8) the juxtaposition of $\mathrm{L}+\mathrm{H}$ and ${ }^{\prime} \mathrm{H}+\mathrm{H}$ respectively at the 
boundary between the noun and its attributive modifier results in a $\mathrm{H}$ tone, in (9) which involve numeral modifiers, a LH contour and a ' $\mathrm{H}$ respectively surface in the outputs, an indication that there is a difference in the tone sequences at the beginning of the modifier. As has been observed in our examples so far and from the forms in (8) below, a basic tone principle in this language is that the $\mathrm{H}$ tone is preserved at the expense of the $\mathrm{L}$ tone, such that the merging of $\mathrm{L}+\mathrm{H}, \mathrm{H}+\mathrm{L}$ or ! $\mathrm{H}+\mathrm{H}$ at grammatical boundaries usually produces a $\mathrm{H}$ tone and not a $\mathrm{LH}$ sequence or ${ }^{\prime} \mathrm{H}$ (even if the $\mathrm{L}$ gets deleted from the phonetic string). Note that we cannot have a sequence of $\mathrm{H}+\mathrm{\prime} H$ because ${ }^{\prime} \mathrm{H}$ is never found in word initial position: it always follows $\mathrm{H}$ within a morpheme.

One way to account for the difference between the outputs in (8) and (9) is to postulate a floating $L$ construction-marking tomorph for (9) but, as we will show later, Urhobo has a floating $\mathrm{H}$ construction marker in certain numeral combinations that would make postulating a floating $\mathrm{L}$ uneconomical.
a. 'ikpè igrógrò
[1kpígrógrò]
'long beds'
b. $\varepsilon^{\prime} s \bar{\varepsilon}$ éróárò
[ésérwárò]
'big fathers'
a. '́kpè ivè
[1kp̌̀vè]
'two beds'
b. és̄érà
[ésērà]
'three fathers'

However, the digits are the only group of words in the language found with a contour tone in the citation form, and this makes the tone sequence suspect as a lexical property of the numerals. Rather, we regard it as a property of the construction so that it is the construction that assigns an initial LH contour to the digits. Evidence that this may actually be the case can be seen in the form for 'eleven' /úhwǒvó/ in the data presented in (12) below where /jvò/ 'one', which is the only digit with an initial L in isolation, surfaces with a LH contour when it combines with the form for 'ten'.

The digits of Urhobo are:

\begin{tabular}{|c|c|c|c|}
\hline (10) j̀vò & 'one' & ěsá & 'six' \\
\hline ไ̌vè & 'two' & $\check{i} \gamma^{\mathrm{w}} \mathrm{r}^{\prime} \varepsilon$ & 'seven' \\
\hline ěrà & 'three' & ¿̌rérē & 'eight' \\
\hline Ěnè & 'four' & írírī & 'nine' \\
\hline íjòrì & 'five' & ihwè & 'ten' \\
\hline
\end{tabular}


In the NP, the numeral modifier follows the $\mathrm{N}$ but it is the final vowel of the $\mathrm{N}$ that either undergoes glide formation if it is [+high] or gets elided if it is [-high] thereby setting its tone afloat. The floating tone merges with the prefix vowel of the numeral resulting in one of three tonal outputs: (i) a LH contour if the combination is a final $\mathrm{L}+$ a numeral-initial $\mathrm{LH}$ as in $\left(11 \mathrm{a}, \mathrm{b}\right.$ ); (ii) a ${ }^{\prime} \mathrm{H}$ if the combination is ${ }^{\mathrm{H}} \mathrm{H}+\mathrm{LH}$ as in $(11 \mathrm{c}$, d); or (iii) a $\mathrm{H}$ if the combination is $\mathrm{H}+\mathrm{LH}$ as in $(11 \mathrm{e}, \mathrm{f})$. Note that in $(11 \mathrm{c}, \mathrm{d})$ the ${ }^{\mathrm{H}} \mathrm{H}$ survives because the immediately following tone is a sequence of $\mathrm{L}+\mathrm{H}$. Where the tone immediately following ' $\mathrm{H}$ is $\mathrm{L},{ }^{\prime} \mathrm{H}$ survives but where it is $\mathrm{H},{ }^{\prime} \mathrm{H}$ deletes as in (8b) above. In (11e, f), the expected HLH triple sequence simplifies to just $\mathrm{H}$ as a result of the principle that $\mathrm{H}$ tones are preserved. This principle of sacrificing L's in favor of H's will also be found in subsequent sections.

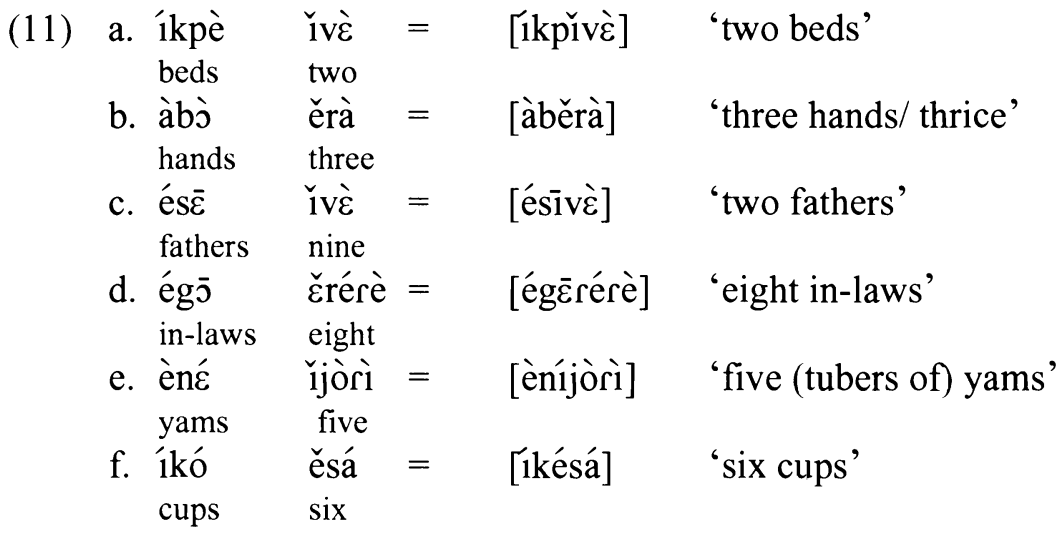

The forms for 'eleven' through 'nineteen' are:

$\begin{array}{ll}\text { úhwǒvó } & \text { 'eleven' } \\ \text { ihwivé } & \text { 'twelve' } \\ \text { ihwěrá } & \text { 'thirteen' } \\ \text { íhwĚné } & \text { 'fourteen' } \\ \text { íhwijórí } & \text { 'fifteen' }\end{array}$

\begin{tabular}{|c|c|}
\hline íhwègběsá & 'sixteen' \\
\hline íhwègbì $\gamma^{\mathrm{w}} \mathrm{r} \check{\varepsilon}$ & 'seventeen' \\
\hline íhwègbžrérē & 'eighteen' \\
\hline íhwègbirírisi & 'nineteen' \\
\hline
\end{tabular}

After the form for 'ten', the only other unique forms are:

${ }^{2}$ In this language, vowels frequently assimilate in roundness or backness to neighboring vowels. This explains why the initial vowel in the form for ' 11 ' is [u] rather than [i]. See also the forms in example (16) below. 


$\begin{array}{lll}\text { (13) ùzè } & - & ' 20 \\ \text { ógbà } & - & ' 30 \\ \text { ùŕ } & - & ' 1,000, \\ \text { òdú } & - & ' 100,000 \\ \text { òdúdùrú } & - & ' 1,000,000 \\ \text { òdúdúmà } & - & ' 1,000,000,000 \\ \text { imà } & - & ' 1,000,000,000,000\end{array}$

As will be noticed from the data in (12), the forms for 'eleven' through 'fifteen' are derived from a combination of 'ten' followed immediately by the forms for 'one' through 'five' with the final vowel of 'ten' elided. In terms of tone, these combinations manifest important tonal modifications. First, the L tone of the elided vowel of 'ten' merges with the L of the LH contour of the combining digit. Second, the initial LH of 'ten' simplifies to H while the L tone(s) of the root in the non-initial number becomes $\mathrm{H}$; this tone raising does not affect all numerals in the construction, just the second one. We can account for this modification by postulating a floating $\mathrm{H}$ tone construction marker for numerals formed from a combination of two numerals in succession. This explains why čnè appears as ̌̌né.

As part of the NP, the tone of the final vowel of the noun gets deleted with its vowel if it is $\mathrm{L}$ or ${ }^{\prime} \mathrm{H}$, leaving only the initial $\mathrm{H}$ tone of the numeral. In this case, the pattern of tone retention on the noun is different than it was in other noun + numeral cases, where those numerals began with a rising tone. In those earlier cases, final ' $\mathrm{H}$ is kept. Now here, ' $\mathrm{H}$ deletes while the initial $\mathrm{H}$ of the numeral is kept. This follows from the basic phonological distinction between the numbers, where there is a level $\mathrm{H}$ in these complex number constructions involving two numerals.

The forms in (14) below are examples of noun plus numeral:
a. 'iwù 'ihwivé = [1wíhwivé]
b. 'ikó
garments
twelve
'12 garments'
cups fifteen '15 cups'
c. és̄̄
'ihwěné
[ésíhwěné]
fathers
fourteen
'14 fathers' 
From 'sixteen' through 'nineteen', the numerals 'six' through 'nine' are added to 'ten' with a conjunctive element [gbì] whose vowel and L tone are always elided. The only tonal modification in these combinations is on the initial vowel of ' 10 ' which also bears $H$ tone: units following [gbغ̀] retain their original tone(s). In the NP, tonal alternations are as in (11) above. Examples include:
a. 'íù íhwègběsá = [1wíhwègběsá] '16 garments'

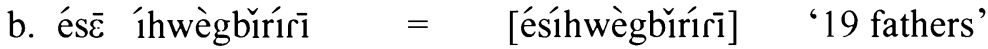
c. '́kó 'ihwègbžrérēe [1ḱihwègbžrérē] '18 cups'

The numerals 'twenty-one' through 'twenty-nine' and 'thirty-one' through 'thirty-nine' are formed by combining 'twenty' or 'thirty' and the relevant digit with [gb̀े] between them. No new tonal alternation occurs in these. From 'forty' onwards, counting is in multiples of 'twenty' and the numerals are formed by combining 'twenty' with the forms for 'one' through 'nineteen'. In these multiples of 'twenty', a H tone emerges between 'twenty' and the combining numeral, evidence of the floating $\mathrm{H}$ construction marker identified earlier which is found in numerals made up of two numerals that follow each other directly without the intervention of [gb̀े].

The forms for 'forty', 'sixty', 'eighty' and 'one hundred' are:
(16) ùzúv̌̌
$[\grave{u} z \grave{e}+(H)+\check{\text { lvě }}]$ 'forty'
ùzórà
$[\grave{u} z \grave{e}+(\mathrm{H})+$ èrà $]$ 'sixty'
ùzŏnè
$[\grave{u} z \grave{e}+(\mathrm{H})+\check{\varepsilon} n \grave{j}]$ 'eighty'
ùzúóri
$[$ ùzè $+(\mathrm{H})+$ ijòri $]$ 'one hundred'

As part of the NP, other tonal alternations result from the principle of $\mathrm{H}$ preservation earlier identified so that even a L-toned number prefix deletes when preceeded by a $\mathrm{H}$ or ' $\mathrm{H}$. Compare the sequences in (17) with those in (18). Notice that there is no rising tone at all in these "multiplicative" structures and there is no prefixal rising tone in éḡ̃ $+\grave{u} z \grave{e}$ 'twenty cups'.
a. 'ikó + ùzúvè
$=[1$ kúzúvè $]$
'40 cups'
b. éḡ + ùzórà
= [égūzórà]
'60 in-laws'
c. àbj̀ + ùzónè
= [àbùzónè]
' 80 hands/times' 
(18)
a. '́kó + ùzègb̌̀vè
$=$ [1kúzègb̌̀v̀̀]
'22 cups'
b. àbj̀ + ùzègběnè
$=$ [àbùzègběnè]
'24 hands/times'
c. éḡ + ùzúvègbíhwěrá
$=$ [égūzúvègbíhwěrá]
'53 in-laws'
d. '́kó + ùzónègb̌̌hwègb̌rírī = [1kúzónègbǐhwègb̌rírī $]$
'99 cups'

The last group of non-associative NPs to be examined here is the Noun + Attributive modifier NP. As Welmers (1969) correctly observes, Urhobo has no word class which can be appropriately labeled 'adjective', rather there are attributive forms which function as adjectives and can be found in both the nonassociative and associative constructions. Some of the non-associative attributive forms are derived from verbs through a process of reduplication and these usually have three or four syllables: those with three syllables bear HHL tones while those with four bear HHLL tones. As modifiers, they follow the noun and one of the following alternations may take place: (i) if both tones at the boundary are identical, they merely collapse into one with the final vowel of the noun deleting as in (19a, b); (ii) if the final vowel of the noun bears a ${ }^{\prime} \mathrm{H}$ or $\mathrm{L}$ and the prefix vowel of the modifier bears $\mathrm{H}$, both the final vowel of the noun and its tone are deleted and replaced by the vowel and tone of the modifier as in (19c-f). If on the other hand the tone of the noun vowel is $\mathrm{H}$ and that of the modifier is $\mathrm{L}$, then the noun vowel and its tone replace the modifier vowel and its tone as in (19g-i).
a. úkó órúárò
[úkórwárò]
cup big
b. ànmá ófúáfò
'a big cup'
cloth white
[ànmófwáfò]
c. ว́ḡ óbiébi
'a white cloth'
in-law black
d. '́ $1 \gamma \bar{o}$
óbúébù
[ógóbjébi]
'a black in-law'
money much/plenty
e. èrù ótèté

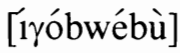
'much/plenty of money'
cap small
f. 'ikpè ijójòvì
beds fine (pl.)
[èrwótèté]
'a small cap'
[1kpíjójòvi]
'nice beds' 

g. ènmá èkpókpò
[ènmákpókpò]
cloths new (pl.)
h. éḡ èkpókpò
'new (pieces of) cloth'
in-laws new $(\mathrm{pl})$
i. úkpè jò̀dè
[éḡ̄kpókpò]
'new in-laws'
bed
a big one
[úkpèròdè]
'a big bed'

It is possible to combine some of these structures, but no new tone changes occur.
a. 'ikpè ítèté ̌̌nè j̀nà
[1kpítèténènà]
beds small four the
'the four small beds'
b. éḡò èkpókpj̀ èsá
[égēkpókpěsá]
in-laws new six
'six new in-laws'
c. 'ikó ìféfè Ěrérē èwé
[1kiféf̌̌rérēwé]
cups empty eight yours
'your eight empty cups'
d. éḡ̃ íbuébù jònà ézóbì ònà
[égíbwébù nézóbì nà] in-laws many the all the
'all the many in-laws'

A close look at the preceding data reveal that the loss of ' $\mathrm{H}$ is not conditioned by the fact that the vowel bearing it is deleted, but rather by the type of tone which immediately follows it: if the following tone is a $\mathrm{L}$ the ${ }^{\prime} \mathrm{H}$ survives, but if the following tone is a $\mathrm{H}$, the ${ }^{\prime} \mathrm{H}$ is lost. The crucial feature of downstep deletion in this language is that $\mathrm{H}$ immediately follows $\mathrm{H}$. This also explains why in $(11 \mathrm{c}, \mathrm{d})$ where ' $\mathrm{H}$ merges with $\mathrm{LH},{ }^{\prime} \mathrm{H}$ survives since it is immediately followed not by $\mathrm{H}$ but by the $\mathrm{L}$ part of the sequence.

In many languages that have downstep, sequences such as (19a) with consecutive $H$ tones in a grammatical sequence (cf. Igbo (Clark 1980)), and (19f) where the L between two $\mathrm{H}$ tones is deleted (cf. Ghotuo (Elugbe 1985)) would trigger downstep, but in Urhobo they do not. In fact, as examples (19c, d), as well as many of the examples in the other sections show, the preservation of $\mathrm{H}$ will result in the replacement of ${ }^{\prime} H$ with regular $H$ rather than the reverse. When ${ }^{\prime} H$ merges with an immediately following $\mathrm{H}$ on one vowel, the result is $\mathrm{H}$ and not ${ }^{\prime} \mathrm{H}$. These facts are worthy of note since they contradict what is usually held in the literature: that downstep results from a lost L tone, or that it is syntactically or grammatically conditioned. Even in the tradition where the downstep is regarded as an entity separate from the $\mathrm{H}$, when $\mathrm{H}$ gets deleted, one does not expect the downstep to also be deleted. Yet, in Urhobo, the deletion of a $\mathrm{H}$ also means the deletion of the preceding downstep. Problems such as these have led some to re- 
gard the third pitch in Urhobo as a mid tone and not ${ }^{\prime} \mathrm{H}$, but its distribution is definitely that of a downstep. Unlike the $\mathrm{M}$ tone in, e.g. Yoruba, no utterance begins with this supposed $M$, and it does not appear after L: no tone rises above it within the phrase. As far as we can tell, the downstep in Urhobo is phonemic and is phonologically 'bound' to the $\mathrm{H}$ tone, and is found as part of the lexical tones of some nouns and numerals. There are no processes in the tonology of this language that actively create downsteps.

2.2 Associative constructions. The associative construction is used to express both a possession relation and an association relation. Its structure is that of a noun and its modifier conjoined by a high-toned independent grammatical morpheme $/ \mathrm{r}^{\prime} /$ which we refer to as the associative marker (AM). The vowel of AM is always elided in normal conversational speech and, in fast speech, even the consonant may be elided, although it is easy to recover both in slow deliberate speech. Its tone is retained and surfaces on the following vowel. Two types of associative constructions are examined: Noun + Noun, and Modifier + Noun.

\subsubsection{Noun + Noun (N1 + N2) Associative construction. This type of NP sig-} nals a possession relation, and the modifier is either another noun or a possessive pronoun other than the first and second person singular forms. For our purposes here, we shall regard these possessive pronouns as nouns. The modifier follows the head noun with the high-toned AM between them. When the vowel of the AM is elided, its high tone obligatorily relinks onto the prefix vowel of N2 and either merges with the tone in that position if it is $\mathrm{H}$, or replaces it if it is $\mathrm{L}$. Thus, only the prefix vowel of $\mathrm{N} 2$ in the output is affected by tone change: it is always $\mathrm{H}$. (Note that the tones involved in this alternation are those of the AM which is $\mathrm{H}$ and the prefix vowel of $\mathrm{N} 2$ which can only be $\mathrm{H}$ or $\mathrm{L}$; ' $\mathrm{H}$ is excluded from these positions). In (21c), because the noun begins with a consonant, a vowel is inserted in the output which then bears the $\mathrm{H}$ tone of AM after it is set afloat. As mentioned earlier, where the lost tone of $\mathrm{N} 2$ is a L, there is no lowering effect on any surviving tone in the sequence. This is because, as has been observed elsewhere (Aziza 2001), although there is downdrift in this language, the second $\mathrm{H}$ of a $\mathrm{H}$ $\mathrm{L}-\mathrm{H}$ sequence is lowered only if the $\mathrm{L}$ is present in the output. If it is deleted before it gets to the surface, it simply disappears leaving no trace on surviving tones. In (21d) there are two levels of the downstep, the first lowers the pitch of the following $\mathrm{H}$ while the second is lower than the first, producing a terracing ef- 
fect. Where the NP is a recursive one as in $(21 \mathrm{~h}, \mathrm{i})$, the same processes observed above also take place with the high-toned AM preceding every additional noun.

(21) a. òbò ré ènì

hand AM elephant

b. úkó ré ógbá ré itivó

Cup AM warlord AM where $\mathrm{Q}$

c. 'íō r'́ Tégà

money AM name

d. 'í $\gamma \bar{o}$ ré óḡ̄ ว̀vó (L)

money AM in-law which Q

e. úkpè ré j̀jè bed AM his

f. ว́ḡ̄ ré àvárē in-law AM we/our

g. àymá ré òwàvá

cloth AM you/your (pl.) [òbò rénì]

'an elephant's hand'

[úkó rógbá rítivô]

'a cup belonging to a warlord from where?'

[1rō ritégà]

'Tega's money'

[íō róḡ̄ vô]

'which in-law's money?'

[úkpè rójè]

'his bed'

[ógō rávárē]

'our in-law'

[ànmá rówàvá]

'your cloth'

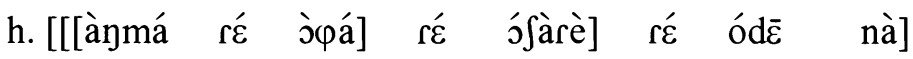
cloth AM bride AM man AM yesterday the

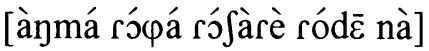
'cloth (belonging to) the yesterday's man's bride'

i. [[òbj̀ ré ènì] ré ijèré] [òbò rénì ríjèré] hand AM elephant AM name of town 'a hand (belonging to) Jesse's elephant'

2.2.2 Modifier + Noun. As mentioned in 2.1 above, there are attributive modifiers which signal an association relation which are actually nouns and feature in structures similar to the N1 + N2 phrase type described above except that in this case, the modifier precedes the noun.

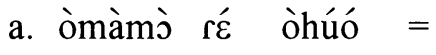
[òmàmò róhwó]
good AM person
'a good person'
b. èràvè r'é áyúá =
[èràvè rárwá]
animal AM bush
'a wild animal' 

c. égòdò ré úfùòmá= compound AM peace
d. iríbó ré inónè = pepper AM today
e. ékpù r'́ àwàrè = bag AM old
f. ékpù ré 'íō = bag AM money
[égòdò rúfwòmá]
'a peaceful compound'
[ìríbó rínónè]
'today's pepper'
[ékpù ráwàrè]
'an old bag'
[ékpù ŕ́rō]
'a bag (containing) money'

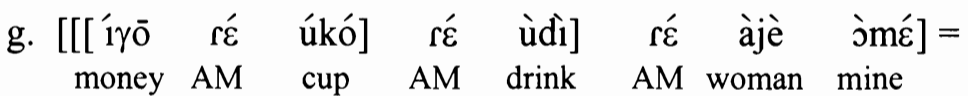
[1 үō rúkó rúdì rájè mé ]

'money for my wife's cup of alcoholic drink'

There is also an associative construction that functions as an adverbial which Welmers lists as a demonstrative, namely jróbồ 'that one over there', pl. èróból 'those'. We treat them as associative constructions and not unanalyzable words for two main reasons: first, although Urhobo has vowel sequences, there are no [oi] sequences, and second, there is actually an approximant / $j$ / between the two vowels which may be elided. Examples of this form include the following. (Only the first example has been broken into its components.)
a. j̀ - r'́ òbóji $=$ [ว̀róbóji]
'that one over there'
pl. [èróbóji]
$3^{\text {rd }}$ pers.sg. AM there
pl. èróbónغ 'these'
b. Jróbón غ̇ 'the one (that is ) here'
pl. èrétiǹ̀ 'these'
c. Jorétın'̀ 'this one here'
pl. èrétiji 'those'
d. Jrétiji 'that one there'

It can also take a demonstrative as in (24) below:
a. ànmá róbónè nà
'the cloth here'
b. éwù rétijì nà
'that dress there'
c. 'íō róbójì nà
'the money over there'

2.3 Noun + Relative Clause. In order to make this section clearer, some preliminary remarks about verbal constructions in Urhobo need to be made. Most of the simple verbs are either monosyllabic or disyllabic and begin with a consonant. 
There are no minimal pairs in the verb class which differ in lexical meaning only as a result of a difference in tone patterning, so that while nouns can be classified according to their tone patterns, verbs cannot be so classified. In the citation form, all verbs (as well as all singular subject pronouns) bear the low tone and, although a number of tonal alternations are attested in verbal constructions, they are usually motivated by the different grammatical configurations. All verbs with the same syllable structure will behave alike in a given verbal construction. Differences in tense and aspect are usually revealed through tonal alternations in the subject NP, or the verb and/or the prefix of the object NP.

For instance, Urhobo marks only three tenses, the present, the past and the future and, apart from the future tense which has an additional tense marker, tenses are differentiated only by tone. There are floating Hs in all tenses, which appear on the final vowel of the subject NP in the present tense, on the final vowel of the verb stem in the past tense and on both the subject NP and the verb in the future tense. The question morpheme is a floating $L$ tone borne by the final vowel of the utterance, while the negative morpheme is a floating LH tone also segmentalized utterance finally. The segmentalization of these floating tones usually causes tonal modifications (often in favor of the $\mathrm{H}$ tone, including creating contour tones) and, in some cases, vowel lengthening. The examples in (25) are for illustration as a full examination of this topic is beyond the scope of this paper. Notice, however, that whereas segmentalization of the floating tones results in the creation of contour tones in $(25 \mathrm{a}, \mathrm{d})$, it results in the deletion of $\mathrm{L}$ tones in $(25 \mathrm{~b}, \mathrm{c})$ while in $(25 \mathrm{e})$ it causes both vowel lengthening and tone contour.
(25) a. j
(H) d̀̀ ว̀n
$=$
[ว̌ dòn $\varepsilon]$
$3^{\text {rd }}$ pers. sg. pres. buy yam
'he/she buys/is buying yam'
$\begin{array}{llll}\text { b. } \begin{array}{l}\grave{d} \\ \text { he/she buy }\end{array} & \text { past } & \text { yam }\end{array}$

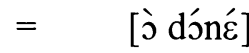
'he/she bought yam'

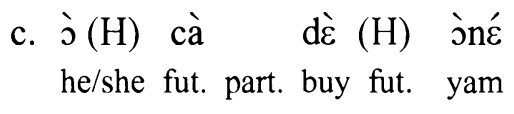
$=\quad$ [ó cà dónć $]$
'he/she will buy yam'

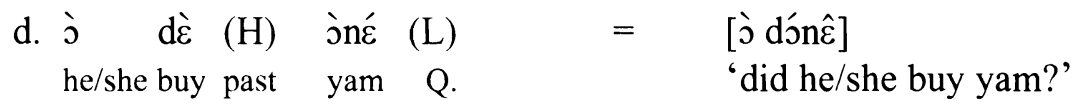
e. j
(H) d̀̀ ว̀n $\quad$ (LH)
$=[\check{\jmath}$ d’̀nćž $]$
he/she pres. buy yam Neg.
'he/she doesn't buy yam' 
The Noun + Relative Clause construction is marked on both the segmental and tonal levels. It is marked by a low-toned relativizer / $/ \grave{\varepsilon} /$ which occurs between the noun and the modifying relative clause and by a floating $\mathrm{H}$ tone which is segmentalized on the final vowel of the subject of the relative clause. The relativizer should not be confused with the AM because, although they are similar in terms of segments (both are / $\mathrm{r} \varepsilon /$ and in both cases the vowel is deleted), they bear different tones: the $\mathrm{AM}$ bears a $\mathrm{H}$ tone while the relativizer bears a $\mathrm{L}$ tone. In addition, the tones of these morphemes behave differently. Whereas the $\mathrm{H}$ tone of the AM does not disappear when its vowel deletes but surfaces on the following vowel and replaces its inherent tone, the $\mathrm{L}$ of the relativizer disappears with its vowel with no effect on surrounding tones.

The subject of the relative clause immediately precedes the verb and its final vowel does not undergo vowel elision or glide formation because the following segment is a consonant. When the $\mathrm{H}$ tomorph construction marker is segmentalized on it, the result is the deletion of the $\mathrm{L}$ or ${ }^{\prime} \mathrm{H}$ inherent tone at the end of the word in that position, so that this vowel always surfaces as $\mathrm{H}$ in the output. It can be seen in the examples in (26) below that this $\mathrm{H}$ tone is there in connection with relative clauses irrespective of whether the head noun is subject or object within the relative clause. In our examples, we identify the relativizer as rel., the subject concord marker as SCM and the floating construction marking tone as RTM (relative tone marker). Note that where both the tense marker and the RTM are segmentalized on the same vowel, the two merely contract into one with no effect on vowel length. In (26c, g, j), the past tense suffix [rè] found in (26a, b, e, f) is deleted because the verb takes an object, the verb stem vowel then gets elided resulting in the past tomorph surfacing on the prefix vowel of the object.
(26)
a. òbò rè ènì
(H) rérè
hand rel. elephant RTM ate
'a hand that an elephant ate'
$=$
[òbò rèní rérè]

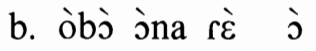
hand the rel. he/she RTM ate
'the hand that he/she/it ate'
(H) rérè
= [òbò nà ró rérè]

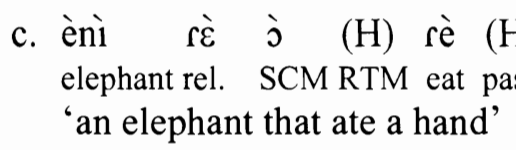
òbò
hand 
d. ènì rè jo $(\mathrm{H})(\mathrm{H})$ rè òbò ònà = [ènì ró rjòbò nà] elephant rel. SCM pres. RTM eat hand the 'an elephant that eats/is eating the hand'

e. úré rè ós $\bar{\varepsilon} \quad(\mathrm{H})$ tòrérè = [úré rósć tòrérè] wood rel. father RTM burnt

'wood that father burnt'

f. úré rè ós s̀ ònà $(\mathrm{H})$ tòrérè = [úré rósē ná tòrérè] wood rel. father the RTM burnt

'wood that the father burnt'

g. ว́s $\bar{\varepsilon}$ rè j̀ $(\mathrm{H})$ tòrè $(\mathrm{H})$ ùwèvì = [ós $\bar{\varepsilon}$ ró tòrúwèvi] father rel. SCM RTM burn past house 'a father that burnt a house'

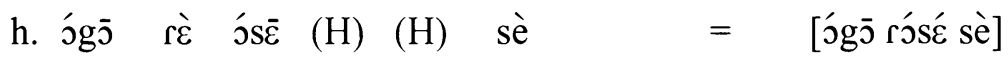
in-law rel. father pres. RTM call 'an in-law that father calls/ is calling'

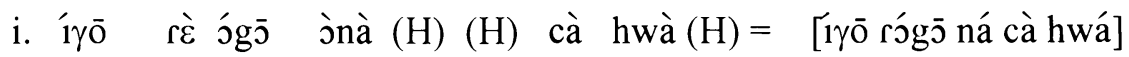
money rel. in-law the fut. RTM part. pay fut. 'money that the in-law will pay'

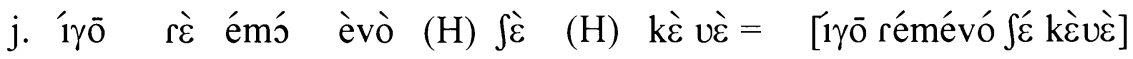
money rel. children some RTM sell past for me 'money that some children sold for me'

In (27) below, we present some examples in context. Notice that any word before the relative clause verb has a final $\mathrm{H}$ and in (27c), we display the two types of $[\mathrm{r} \varepsilon]$ in the complex NP: the first one, the associative marker, which joins two nouns bears a high tone while the second one, the relativizer, which joins the first NP to the relative clause bears a low tone, although after relevant phonological processes have taken place, both are indistinguishable 
a. mè mré òbò rè ènì $(\mathrm{H})$ rérè $\quad$ [mè mróbj̀ rèní rérè]

I saw hand rel. elephant RTM ate

'I saw a hand that an elephant ate'

b. òbò rè ènì $\quad(\mathrm{H})$ rérè ójè mé mrérè = [òbò rèní rérè ójè mé mrérè] hand rel. elephant RTM ate that I saw

'a hand that an elephant ate was what I saw'

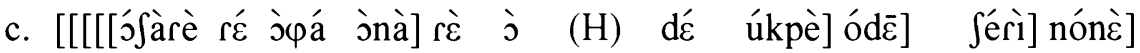

man AM bride the rel. SCM RTM bought bed yesterday fell today = [ó àrè rópá nà ró dúkpè ódē férì nónc̀]

'the husband of the bride who bought a bed yesterday fell down today'

From the foregoing, it is easy to observe that the tone change, even here, is not due to vowel deletion, but rather to the affiliation of a floating tone.

2.4 Tonal alternation in Noun/NP doubling. Noun/noun phrase doubling is a syntactic construction used in Urhobo to express some type of quantification equivalent to the English noun phrases: 'every/each + noun' and 'only/so many or much + noun'. The construction is marked on both the segmental and tonal levels. A low-toned independent morpheme $[\mathrm{k} \dot{\varepsilon}]$ precedes the noun and both the morpheme and the noun are duplicated to make up the noun phrase. The vowel of $[\mathrm{k} \dot{\varepsilon}]$ together with its $\mathrm{L}$ tone are elided while the consonant joins the following noun by resyllabification. A floating $\mathrm{H}$ tone construction marker (which we identify as the double construction tone marker (DTM) surfaces on the right end of the first noun and the result is that an underlying $\mathrm{L}$ or ${ }^{\prime} \mathrm{H}$ in that position becomes $\mathrm{H}$ in the output. Only the right edge of the first noun is affected by tonal modification, all other tones remain intact. The NP may be further modified by an 'adjective' which is also doubled as in $(28 \mathrm{~g}, \mathrm{~h})$. We have used this NP type in complete clauses in those last two examples to show its behavior in fuller sentential context: the doubling of segments does not proceed beyond the 'adjective' and the tone principles of the preservation of $\mathrm{H}$ remain the same, but note that the floating $\mathrm{H}$ will appear on a postnominal adjective, if the noun phrase contains a modifer. Tense tones have not been further analyzed. In $(28 \mathrm{~h})$ both the associative and relative clause markers are involved and the results are as expected. 


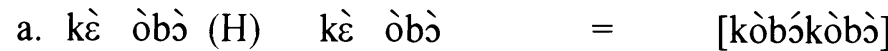
part. hand RDTM part. hand

'every/each hand'

b. kc̀ ófàrè $(\mathrm{H}) \quad \mathrm{k} \varepsilon$ ófàrè

$=\quad$ [kófàrékófàrè $]$ part. man RDTM part. man

'every/each man'

c. kè úkó $(\mathrm{H})$ kè úkó
part. cup RDTM part. cup

$=\quad$ [kúkókúkó]

'every /each cup'

d. kè iŕíbó $(\mathrm{H}) \mathrm{k} \varepsilon$ iríbó part. pepper RDTM part. pepper

$=\quad$ [kiríbókìríbó]

'every/each pepper'

e. $k \grave{\varepsilon}$ óg $\bar{\jmath} \quad(H) \quad$ kè óg
part. in-law RDTM part. in-law

$=\quad[$ kógókóḡ̄]

'every/each in-law'

f. $k \grave{\varepsilon}$ èwérī $(\mathrm{H})$ k̀̀ èwérī = [kèwérikèwérī] part. monkey RDTM part.monkey

'every/each monkey'

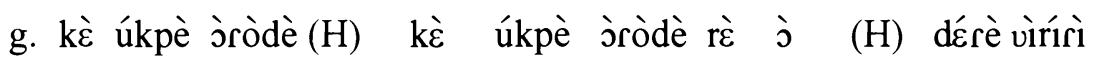
part. bed big RDTM part. bed big rel. he/she RTM bought broke =[kúkpè ròdé kúkpè ròdè ró dérè viríri] 'each/every large bed that he/she bought got broken'

h. kè òmàmò ré èwérī $(\mathrm{H})$ kè òmàmò ré èwérī rè ó $(\mathrm{H})$ cà Part. good AM monkey RDTM part. good AM monkey rel. he fut. RTM dé cà jé buy fut. run

$=$ [kòmàmò réwérí kòmàmò réwérī ró cà dé cà jé]

'each /every good monkey that he/she will buy will run (away).'

In these sequences too, $\mathrm{L}$ and ' $\mathrm{H}$ delete in the presence of floating $\mathrm{H}$, also not involving vowel fusion

2.5 Tonal alternation in noun reduplication. This construction conveys the meaning 'only/so many or much + noun' and affects mainly the plural form of the noun. As mentioned earlier, pluralization is by prefix vowel alternation. This NP type is not marked by any independent segment rather, all the sound segments of the first occurrence of the noun except the prefix vowel and the initial consonant segment(s) fuse with the duplicate. Other words that follow the noun within the 
phrase are not copied. In terms of tone, a floating $\mathrm{H}$ toned reduplication marker (RM) surfaces on the prefix vowel of the noun duplicate resulting in the replacement of $\mathrm{L}$ or ' $\mathrm{H}$ in that position. Examples include the following.
(29)
a. àbò $(\mathrm{H})$ àbò
$=$ [àbábう̀]
hands RDTM hands
'only/so many hands'
b. és $\bar{\varepsilon} \quad(\mathrm{H})$ és $\bar{\varepsilon}$
fathers RM fathers
$=[$ ésés $\bar{\varepsilon}]$
c. '́brō $(\mathrm{H})$ íbrō ré èń́
halves RDTM halves AM yams
'only/so many fathers'
[ibríbrō réné]
'only/so many half (tubers of) yam'

\section{Summary and conclusion}

In this paper, we have described tonal alternations as they occur in different types of noun phrases in Urhobo. The noun phrases were divided into four main groups: the non-associative, the associative, the noun + Relative clause and noun reduplication constructions, each with a number of sub-types. One obvious fact is that floating grammatical tones exist and are commonly used to mark various grammatical constructions in this language. In all the NPs examined, tonal alternations affect only sequences at word boundaries and result from either the merging of vowels or the segmentalization of floating grammatical tones. From the evidence at our disposal, the behavior of tones in the NP illustrate a general principle that $\mathrm{H}$ tones are preserved at the expense of $\mathrm{L}$ tones. In addition, when ${ }^{\prime} \mathrm{H}$ merges with an immediately following $\mathrm{H}$ on the same vowel, the result is $\mathrm{H}$ rather than ${ }^{\prime} \mathrm{H}$, an indication that ' $\mathrm{H}$ is this language may have a phonemic status; more so that the phenomenon is found only as part of the lexical make-up of some nouns. There is also evidence that grammatical tones have more relevance in the grammar of this language than lexical tones. so that $\mathrm{L}$ and ${ }^{\prime} \mathrm{H}$ delete in the presence of floating grammatical $\mathrm{H}$ even where vowel fusion may not be involved. 


\section{REFERENCES}

Aziza, Rose O. 1997. Urhobo Tone System. Ph.D Thesis, University of Ibadan.

Aziza, Rose O. 2001. "An overview of the tone system of Urhobo". Paper read at the $32^{\text {nd }}$ ACAL, University of California, Berkeley, March 23-25, 2001.

Clark, Mary M. 1980. "On the treatment of syntactically distributed downstep". Studies in African Linguistics 11: 101-137.

Elugbe, Ben O. 1973. A Comparative Edo Phonology. Ph.D Thesis, University of Ibadan.

Elugbe, Ben O. 1985. "The tone system of Ghotuo". Cambridge Papers in Phonetics and Experimental Linguistics 4: 1-21

Elugbe, Ben O. 1989. Comparative Edoid: Phonology and Lexicon. Delta Series, No. 6. Port Harcourt: University of Port Harcourt Press.

Kelly, John. 1969. “Urhobo". Twelve Nigerian Languages, ed. by Elizabeth Dunstan. London: Longman. Pp. 153-161.

Welmers, William E. 1969. "Structural notes on Urhobo". Journal of West African Languages 1: 85-107.

Welmers, William E. 1973. African Language Structures. Los Angeles: University of California Press.

Department of Languages and Linguistics

Delta State University

Abraka, Nigeria

roaziza12@yahoo.com
[Received June 22, 2003 accepted June 15, 2004] 
